\title{
Rifampicin: The Investigation of a Bactericidal Antileprosy Drug
}

\author{
R. J. W. REES \\ National Institute for Medical Research \\ Mill Hill, London, NW7 IAA
}

\begin{abstract}
The purpose of this paper is first to present briefly some general conclusions that have emerged from our experience in the use of rifampicin mainly in the Leprosy Research Unit, National Leprosy Control Centre, Sungei Buloh, Malaysia, and more recently in the Medical Research Council Leprosy Research Project, Addis Ababa, Ethiopia; and secondly, to report in more detail on some of the special studies from which this experience has been derived.
\end{abstract}

We have treated about 100 patients with rifampicin in the past 6 years. Almost all of them have been suffering from active lepromatous leprosy (LL-LI: Ridley and Jopling, 1966; Ridley and Waters, 1969); some had received no previous treatment, but the majority had developed dapsone resistance. However, data from such dapsone resistant cases with active disease should in general be applicable to all patients with lepromatous leprosy.

General conclusions from these studies may be summarized as follows:

(1) The Morphological Index (MI) falls more rapidly than in patients treated with dapsone.

(2) Clinical improvement in the first 6 months or so of treatment is more rapid than under dapsone therapy.

(3) Over a period of up to 4 years the fall in the Bacterial Index (BI) is no more rapid than that seen in patients treated with dapsone or clofazimine.

(4) Contrary to our expectations, erythema nodosum leprosum (ENL) is no more frequent or severe than under dapsone therapy.

Rifampicin was originally tested in the mouse footpad for activity against Mycobacterium leprae and it was shown to be equally effective against both dapsone sensitive and dapsone resistant strains (Rees, Pearson and Waters, 1970; Rees, personal communication). A very rapid fall in the MI (to baseline values within 4 weeks) was observed in our initial, pilot, clinical trial, implying that the drug possessed powerful bactericidal activity (Rees, Pearson and Waters, 1970). These experimental findings have been confirmed and extended by Holmes and Hilson, 1972; Shepard et al., 1971 and Shepard, Levy and Fasal, 1972a,b).

The next phase of our investigations was designed to determine the rate at which rifampicin killed Myco. leprae in man. Patients with active lepromatous leprosy were treated with rifampicin $600 \mathrm{mg}$ daily or dapsone $100 \mathrm{mg}$ daily, and Myсо. leprae obtained from biopsies of skin taken at intervals during the trial were monitored for the presence of viable bacilli by mouse footpad inoculation. 
This study (Rees, Pearson and Waters, 1970) showed that Myco. leprae in the skin was rapidly killed by rifampicin since af ter only 3-24 days treatment viable bacilli could no longer be recovered, whereas in contrast viable bacilli were still recovered after 69 days treatment with dapsone. Similar or even more rapid killing of Myco. leprae in the skin of rifampicin treated patients has been reported by Shepard, Levy and Fasal, 1972a,b and Levy, Shepard and Fasal, 1973.

With this clear evidence from experimental and clinical studies that rifampicin was highly bactericidal against Myco. leprae on daily doses of $600 \mathrm{mg}$ in man, or its equivalent in animals, subsidiary and exploratory clinical trials were undertaken to study the efficacy of lower daily doses (20,60 and $150 \mathrm{mg}$ rifampicin) and $600 \mathrm{mg}$ doses given intermittently. These modifications seem justified on the basis of the high activity of rifampicin against Myco. leprae, but also had an essentially practica! approach because of the very high cost of the drug.

The pilot trial of smaller doses of rifampicin was designed entirely to determine whether doses less than $600 \mathrm{mg}$ daily were active. Therefore the trial lasted only 2 months and was assessed primarily on bacteriological criteria by measuring the viability of Myco. leprae in the skin by the MI and mouse footpad test. By these criteria all 3 lower doses were shown to be active against Myco. leprae, although their rate of killing was slower than that obtained with $600 \mathrm{mg}$ rifampicin daily. These short-term results do not prove the efficacy of low dose rifampicin therapy for long-term treatment of lepromatous leprosy. However, the results are important in showing that rifampicin is still bactericidal at a dose of $20 \mathrm{mg}$ daily, and therefore this dose in combination with dapsone for a limited initial period might prove highly efficacious, as related to the small increased cost.

The second and probably more important exploratory clinical trial is concerned with rifampicin therapy on an intermittent basis because of its high bactericidal activity against Myco. leprae. Our intermittent rifampicin treatment trials have been started in Malaysia and Ethiopia and are based on a dosage of $600 \mathrm{mg}$ rifampicin on 2 consecutive days once a month. These are in too early a stage to report clinical results. Unfortunately, in the field of tuberculosis chemotherapy it is well recognized that intermittent rifampicin regimens give rise to a high proportion of "adverse immunological-type reactions" frequently associated with circulating rifampicin-dependent antibodies (Aquinas et al., 1972). In tuberculosis these adverse reactions have occurred in intermittent rifampicin therapy given once weekly and are more frequent when the dose of rifampicin exceeds $600 \mathrm{mg}$. There is no experience on the intermittent regimen we have chosen and therefore it is encouraging that to date no adverse reactions have occurred and no circulating rifampicin-dependent antibodies have been detected in some 30 patients who have been given once monthly rifampicin over a period of about 12 months.

The final part of this paper is a progress report on the study described at the 10th International Leprosy Congress, Bergen, in 1973 (Rees et al., 1973). The advent of a bactericidal drug of fered hope that patients could be cured by shorter periods of therapy than are currently employed using dapsone. We investigated this possibility by studying groups of patients treated with rifampicin $600 \mathrm{mg}$ daily (combined with thiambutosine) for 6, 12 and 24 months. Each patient was subjected to biopsy of the skin, peripheral nerve, striated muscle, and smooth (dartos) muscle, and the specimens inoculated into the footpads of thymectomized-irradiated and normal mice. These tissues were chosen as preferred sites where there is good evidence that Myco. leprae persists in spite of 
dapsone therapy (Pearson, Rees and Weddell, 1970; Waters et al., 1974). Our hope was that, after 2 years of treatment (or possibly less) no viable bacilli would be detected in these sites. If this were the case, it would be justifiable to discontinue antileprosy treatment, while continuing careful clinical observation together with repeated site monitoring in mice to detect relapses at the earliest possible moment.

The results of these studies have clearly shown that unfortunately our hopes of a quick "cure" by rifampicin have been disappointing. Thus, in 6 patients given rifampicin for 6 months, 10 given rifampicin for 12 months and 10 patients given rifampicin for 2 years, a proportion still harboured living bacilli after each period of treatment at one or other of the selected sites as demonstrated by their ability to multiply in the footpads of mice. To date, bacilli isolated in mice from 3 of the rifampicin treated patients have been shown on mouse passage to be rifampicin sensitive. There is clearly a persister problem with rifampicin, as with dapsone and other antileprosy drugs, and 2 years is not long enough to "cure" patients with lepromatous leprosy.

It is still possible that rifampicin will "cure" lepromatous leprosy more quickly than dapsone; maybe 3 years treatment will be enough. These studies are continuing. However, patients with lepromatous leprosy are known to have very low specific cell-mediated immunity with which to deal with their bacilli, and 2 years treatment with a highly bactericidal drug, such as rifampicin, has not sterilized their tissues of viable Myco. leprae. One must conclude, not with an answer but a question: can patients with lepromatous leprosy ever be cured by chemotherapy alone?

\section{Acknowledgements}

All the data presented in this paper is part of coordinated chemotherapeutic trials undertaken by the Medical Research Council at the Leprosy Research Unit in Malaysia and more recently in Ethiopia. The trials reported here were coordinated from the National Institute for Medical Research, London, and the clinical conduct and expertise undertaken by Drs J. M. H. Pearson and M. F. R. Waters. The mouse footpad studies were undertaken in London on refrigerated tissues despatched by air. The assessments of rifampicin-dependent antibodies were undertaken by Dr Sheila Worlledge of the Department of Haematology, Royal Postgraduate Medical School, Hammersmith. Messrs Gruppo Lepetit of Milan generously provided free all the rifampicin.

\section{References}

Aquinas, M., Alan, W. G. L., Horsfall, P. A. L., Jenkins, P. K., Wong, Hung-yan, Girling, D., Tall, R. and Fox, W. (1972). Adverse reactions to daily and intermittent rifampicin regimens for pulmonary tuberculosis in Hong Kong. Br. med. J. 1, 765.

Holmes, I. B. and Hilson, G. R. F. (1972). The effect of rifampicin and dapsone on experimental Mycobacterium leprae infections; minimum inhibitory concentrations and bactericidal action. J. med. Microbiol. 5, 251.

Levy, L., Shepard, C. C. and Fasal, P. (1973). Death of Myco. leprae following treatment of leprosy patients with $1500 \mathrm{mg}$ in a single dose. Int. J. Lepr. 41, 490.

Pearson, J. M. H., Rees, R. J. W. and Weddell, A. G. M. (1970). Mycobacterium leprae in the striated muscle of patients with leprosy. Lepr. Rev. 41, 155.

Rees, R. J. W., Pearson, J. M. H. and Waters, M. F. R. (1970). Experimental and clinical studies on rifampicin in the treatment of leprosy. Br. med.J. 1, 89. 
Rees, R. J. W., Waters, M. F. R., Pearson, J. M. H., Helmy, H. S., McDougall, A. C., Weddell, A. G. M. and Edwards, Rose (1973). Rifampicin: Assessment of a bactericidal drug in the treatment of lepromatous leprosy. Int. J. Lepr. 41, 681.

Ridley, D. S . and Jopling, W. H. (1966). Classification of leprosy according to immunity. A five-group system. Int. J. Lepr. 34, 255.

Ridley, D. S. and Waters, M. F. R. (1969). Significance of variations within the lepromatous group. Lepr. Rev. 40, 143.

Shepard, C. C., Levy, L. and Fisal, P. (1972a). Rapid bactericidal effect of rifampicin on Mycobacterium leprae. Am. J. trop. Med. Hyg. 21, 446.

Shepard, C. C., Levy, L and Fasal, P. (1972b). Rifampicin and Myco. leprae. Int. J. Lepr. 40, 459.

Shepard, C. C., Walker, L. L., Van Landingham, R. M. and Redus, M. (1971). Kinetic tesíng of drugs against Mycobacterium leprae in mice. Activity of cephaloridine, rifampicin, streptovaricin, and viomycin. Am. J. trop. Med. Hyg. 20,616.

Waters, M. F. R., Rees, R. J. W., McDougall, A. C. and Weddell, A. G. M. (1974). Ten years of dapsone in lepromatous leprosy: Clinical, bacteriological and histological assessment and the findings of viable leprosy bacilli. Lepr. Rev. 45, 288. 